Arq. Bras. Med. Vet. Zootec., v.70, n.2, p.401-409, 2018

\title{
Evaluation of the presence of Leishmania infantum in bone stored in glycerol or sterilized by autoclave for cortical bone grafting
}

[Avaliação da presença de Leishmania infantum em ossos armazenados em glycerol ou esterilizados em autoclave para enxertia óssea cortical]

\author{
M.A.M. Lopes ${ }^{1}$, S.O. Silva ${ }^{2}$, I.F.G. Amorim², W.L. Tafuri' ${ }^{2}$, M.N. Melo², C.M.F. Rezende ${ }^{1 *}$ \\ ${ }^{1}$ Escola de Veterinária - Universidade Federal de Minas Gerais - UFMG - Belo Horizonte, MG \\ ${ }^{2}$ Instituto de Ciências Biológicas - Universidade Federal de Minas Gerais - UFMG - Belo Horizonte, MG
}

\begin{abstract}
This study was performed to evaluate the effects of autoclaving and storage in $85 \%$ glycerol on cortical bone from dogs infected with Leishmania sp. We used 42 cadavers with leishmaniasis. The dogs were evaluated for the presence of Leishmania sp. in culture of bone marrow and by culturing cortical bone. From the infected animals, we harvested 42 diaphysis of the right femur for culture of cortical bone before and after autoclaving or storage in glycerol. There was no significant difference in growth of the parasite in culture of bone marrow or cortical bone. There was no growth of Leishmania sp. in culture of samples after autoclaving or storage in glycerol. Both treatments were effective in preventing the growth of the parasite in vitro, so it was considered viable for grafting.
\end{abstract}

Keywords: bone graft, canine visceral leishmaniasis, glycerol, sterilization

\section{RESUMO}

Este estudo teve por objetivo avaliar os efeitos da esterilização em autoclave e do armazenamento em glicerol a 85\% no osso cortical de cães infectados por Leishmania sp. Foram utilizados 42 cadáveres de cães com leishmaniose. Os cães foram avaliados para a presença de Leishmania sp. em cultura de medula óssea e de osso cortical. Foram coletadas 42 diáfises do fêmur direito para cultura do osso cortical antes e após a esterilização e o armazenamento em glicerol. Não houve diferença significativa no crescimento do parasito em cultura utilizando-se medula óssea ou osso cortical. Não houve crescimento de Leishmania sp. em cultura de amostras de osso cortical após a autoclavagem ou o armazenamento em glicerol. Ambos os tratamentos foram eficazes na prevenção do crescimento do parasita in vitro, de modo que foram considerados viáveis para enxerto.

Palavras-chave: enxerto ósseo, leishmaniose visceral canina, glicerol, esterilização

\section{INTRODUCTION}

Visceral Leishmaniasis (VL) is a zoonosis transmitted by vectors Diptera: Psycodidae: Phlebotominae, and results from the replication of parasites in the mononuclear phagocyte system. It is caused by parasites of the Leishmania donovani complex, which includes $L$. donovani and $L$. infantum. Infection with $L$. infantum in dogs is endemic in approximately 50 countries in Europe, Africa, Asia, the

Recebido em 18 de agosto de 2016

Aceito em 19 de outubro de 2016

* Autor para correspondência (corresponding author)

E-mail: cleuzaufmg@gmail.com
Mediterranean area and the Americas (Alvar et al., 2004). Brazil is a country that has high rates of the disease, with the highest concentration of cases in the Northeast and North regions, followed by the Southeastern and Midwest, with growing numbers of cases in urban areas such as in the city of Belo Horizonte (Leishmaniose..., 2012).

Canine Visceral Leishmaniasis (CVL) caused by $L$. infantum is a disease in which infection does not guarantee clinical disease, leading to a high 
prevalence of subclinical infections (Baneth et al., 2008). Classically, CVL is described as a disease characterized initially by fever, dermatitis, alopecia, desquamation and ulceration often located on the ears, nose and tail joints (decubitus ulcers). Osteoarticular involvement in cases of CVL has been described in dogs with lameness, polyarthritis and osteomyelitis associated with systemic disease (Santos et al., 2006 and Costa et al., 2006).

Transmission is primarily through a blood meal by infected sand flies. Other forms of transmission have been reported, such as blood transfusions (Freitas et al., 2006), which suggests the same possibility for grafts and organ/tissue transplants, among these bone grafts. Therefore, with the spread of infection by Leishmania infantum, it became impractical to harvest bone from animals euthanized for irrecoverable nerve damage whose previous history was unknown. This led to a drastic reduction and even closing of bone banks, which are necessary and useful in situations requiring orthopedic cortical bone grafts.

The use of bone grafts is a common practice in small animal orthopedic surgery and allows healing of different magnitudes of bone injury (Cavassani et al., 2001). The grafts play an osteogenic and/or mechanical support function, depending on the type used (Fitch et al., 1997). The cortical grafts are used in situations that require structural support, such as repairing comminuted fractures (Torres et al., 2009) and preserving limbs after tumor excision (Morello et al., 2001).

Because studies on the infection of healthy animals by Leishmania sp. through cortical allografts where not found in the literature, this study aimed to evaluate the presence of the parasite in cortical bone after autoclaving or storage in glycerol at $85 \%$ PA for 30 days and to evaluate the compressive strength and histological changes of the bone tissue. The favorable outcome, i.e., the elimination of infection and the absence of significant changes that impair the quality of the graft, will allow the maintenance and expansion of bone banks.

\section{MATERIAL AND METHODS}

All cadavers used were derived from dogs that died or were euthanized at the Veterinary Hospital of the Universidade Federal de Minas Gerais (UFMG). There were no experiments on living animals or any involvement with their death or euthanasia methods. Even so, the project was approved by the Animal Experimentation Ethics Committee from Universidade Federal de Minas Gerais (CETEA - Comitê de Ética em Experimentação Animal) under protocol number 266/2011.

Forty two cadavers without selection for breed or gender were used to develop this study. The animals died or were euthanized due to infection by Leishmania and had, necessarily, positive serology for leishmaniasis (reaction tests using immunofluorescence - IFA - and Enzyme Linked Immunoabsorbent Assay - ELISA). Serologic testing was performed by private laboratories, the Laboratory of Leishmaniasis from the Department of Epidemiology and Centers for Zoonosis Control of the Municipal Secretariat of Health of Belo Horizonte (MSH).

Sample collection from the animals naturally infected by Leishmania infantum was performed with sterile instruments after shaving and antisepsis of the right hindlimb and isolation of the area with sterile cloths. The samples were collected by an appropriately attired person in a surgery room of the small animal Veterinary Hospital of UFMG. The approach to the femur proceeded with a cranio-lateral skin incision from the hip joint to the proximal tibia. Subsequently, an incision in the fascia lata and removal of the femoral biceps and vastus lateralis were performed, resulting in exposure of the femur. The muscles around the bone were sectioned at their insertions with a scalpel, releasing the entire shaft. Then, muscles and extra and intra - articular ligaments were sectioned in the femoro - tibial - patellar and coxofemoral joints, with resection of the bone (Fig. 1a and 1b). Once removed, the bone was sectioned with the aid of a sagittal saw in the proximal metaphyseal region, removing the femoral head and neck (Fig. 1c). The bone marrow was removed from the bone canal with 
an intramedullary pin or an anatomical forceps

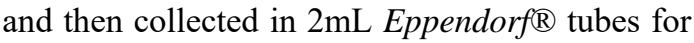
refrigeration (Fig. 1d). The diaphyseal cortical bone was divided into two parts, the first being fragmented into several small particles of approximately 0.3 to $0.55 \mathrm{~cm}$ with a clamp gouge. These fragments were pooled and washed with $0.9 \%$ saline solution until complete removal of the bone marrow and adjacent soft tissues occurred (Fig. 1e and 1f). The samples were placed in $2.0 \mathrm{~mL}$ Eppendorf® tubes and in $50 \mathrm{~mL}$ Falcon ${ }^{\circledR}$ tubes containing $85 \%$ glycerol PA. One Eppendorf® tube containing material was destined for culture, and the other was autoclaved before placing its content in culture medium.

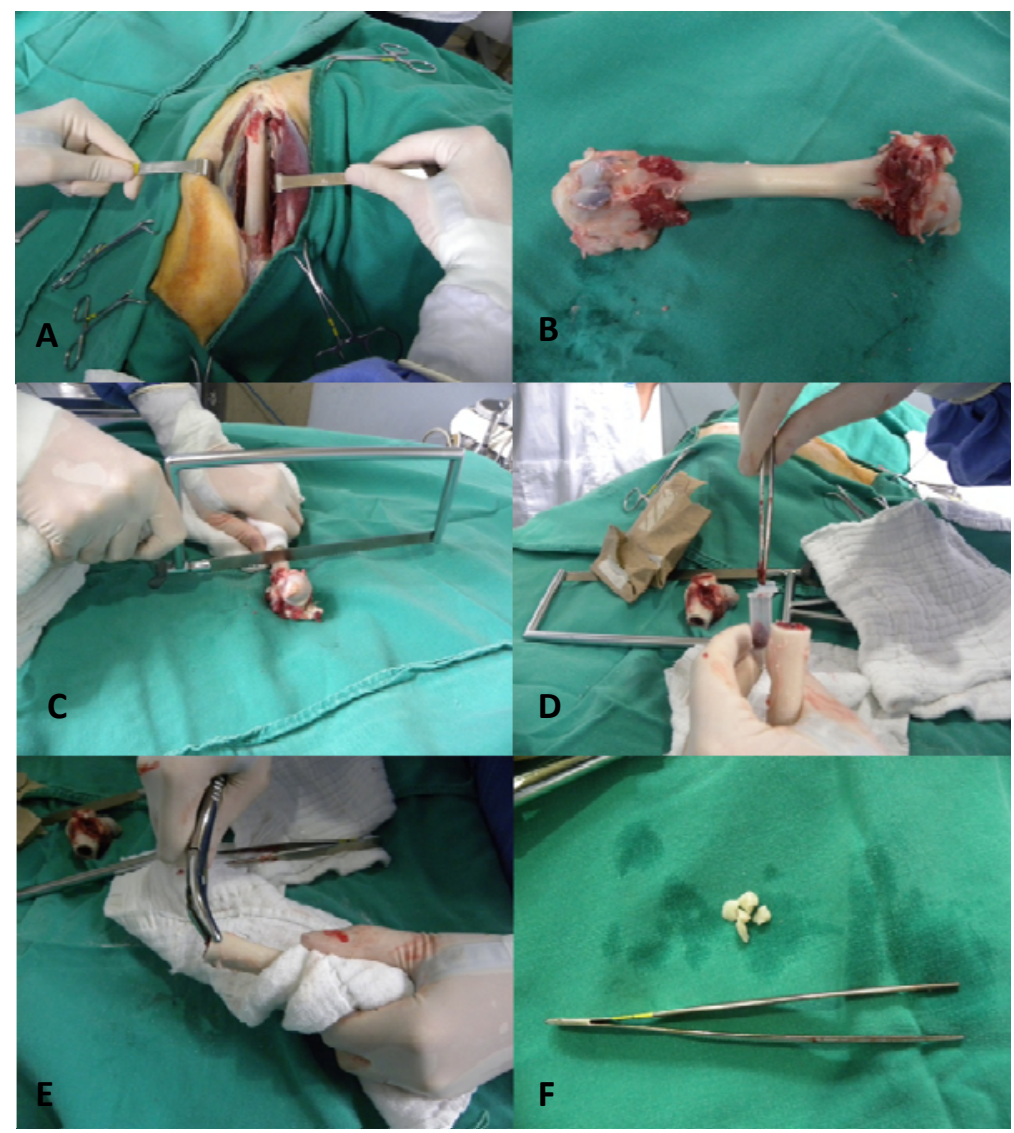

Figure 1. Femoral collection procedure from dogs infected with Leishmania. A: Femoral exposure. B: Femur removed. C: Section of femoral head and neck with sagittal saw. D: Bone marrow storage in Eppendorf® tube. E: Fragmentation of the femoral shaft with gouge forceps. F: Diaphyseal fragments after washing with saline $0.9 \%$.

Samples from cortical bone and marrow from the animals were separately cultured at the Laboratory of Biology of Leishmania from the Department of Parasitology, Institute of Biological Sciences. Approximately $0.3 \mathrm{~mL}$ of marrow was added to the culture medium. The fragments of cortical bone were included in the medium at an amount of approximately $30 \mathrm{mg}$. The process was performed inside a laminar flow hood (VECO, Campinas, São Paulo, Brasil) in sterile glass tubes containing biphasic culture medium NNN - Novy, McNeal and Nicolle
(Evans 1989) supplemented with MEM (Minimum Essential Media, GIBCO ${ }^{\circledR}$, Life Technologies, Langley, Oklahoma, USA) containing 10\% Fetal Bovine Serum (FBS). The samples were kept in a cooled incubator

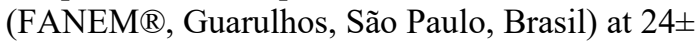
$1{ }^{\circ} \mathrm{C}$. Every 10 days the cultures were examined to evaluate the presence and multiplication of promastigotes of Leishmania. up to two subcultures were made, including a portion of the first tube into another with new medium. 
Samples that had growth of promastigotes were cryopreserved in liquid nitrogen.

Bones for storage in $85 \%$ glycerol PA remained in $50 \mathrm{~mL}$ Falcon ${ }^{\circledR}$ sterile tubes with glycerol for 30 days. The treatment by autoclaving was carried out at a temperature of $120^{\circ} \mathrm{C}$ for 30 minutes, and the Eppendorf $\AA$ tubes containing the samples were slightly open but covered with aluminum foil. After undergoing one of the treatments, the samples were inoculated into culture medium for Leishmania the same way as described for untreated samples.

Material from bone marrow and lymph nodes was used to prepare slides with smears by extension that were subsequently stained with Quick Panoptic ${ }^{\circledR}$ (Laborclin, Pinhais, Paraná, Brasil) and evaluated for the presence of the parasite.

The selection of statistical tests for each item studied in this work was made according to Sampaio (2002). The effectiveness of the two treatments applied to cortical bone (glycerol storage and sterilization by autoclaving) was evaluated by a McNemar test, which compared the control group with each treatment separately. A comparison between the number of positive samples from bone marrow and cortical bone in culture was performed by analysis of variance (ANOVA) and a Fisher's test.

\section{RESULTS}

The results of the evaluation of the growth of Leishmania infantum in culture are shown in Table 1 and Figure 2. There was growth of Leishmania infantum in cultures from 27 bone marrows and 22 cortical bone samples, with no significant difference in isolation of the parasite between these tissues $(\mathrm{P}>0.05)$.

An interesting fact was that it was possible to isolate $L$. infantum from samples collected from cadavers 48 hours post-mortem and after refrigeration.

From twelve animals, there was no growth of the parasite in culture medium in any of the samples prepared. Samples from four animals were contaminated with bacteria or fungi and, from two other, the parasite Erlichia canis was observed in the bone marrow smear.
No samples showed growth of Leishmania infantum after storage in glycerol for 30 days, including those positive prior to storage/treatment. Statistical analysis showed a significant difference $(\mathrm{P}<0.0001)$ between the untreated group and the glycerol group.

In the present study, despite aseptic sample collection, some cultures containing tissues preserved in glycerol showed slight bacterial growth.

As for the autoclaved samples, none showed growth of Leishmania infantum. There was a significant difference $(\mathrm{P}<0.0001)$ between the control (untreated) group and the sterilized group.

\section{DISCUSSION}

The similar rate of isolation of the parasite in cortical bone and bone marrow could be explained by the fact that Leishmania invades osteoclasts, which are part of the monocytephagocyte system (Alvar, et al., 2004). Furthermore, the proximity of the cortical bone to the marrow, which is one of the most affected tissues in animals with visceral leishmaniasis (Tafuri et al., 2001 and Solano-Gallego et al., 2007), could promote extension of infection into this tissue.

The contamination of samples with fungi or bacteria damaged the possible growth of Leishmania infantum in four samples. The samples that showed another parasite (E. canis) in the bone marrow smear could have been positive in serological examination by cross reaction without the animal being infected by Leishmania. Cross reaction between visceral leishmaniasis and Babesia canis infection by dot - ELISA was observed in a dog by Mancianti et al. (1996) and in dogs infected with B. canis and Ehrlichia by IFA and ELISA (Gomes and Cordeiro, 2004; Ferreira et al., 2007). Troncarelli et al. (2008) reported cross-reaction between Leishmania and Trypanosoma cruzi by IFA testing because of the phylogenetic affinity of these agents. For the remaining six animals whose samples did not grow in culture, it is suspected that there were false positive serological results (for those with a negative bone marrow smear) or that the parasite load in the tissue was not sufficient to allow growth in culture medium (Navin et al., 1990). 
Table 1. Positive animal's ratio, gender, race, age and income for the culture of promastigotes of Leishmania infantum in bone marrow and cortical bone before processing and after sterilization or storage in glycerol

\begin{tabular}{|c|c|c|c|c|c|c|c|}
\hline Animal & Gender & Race & Age & $\begin{array}{l}\text { Unprocessed } \\
\text { bone marrow }\end{array}$ & $\begin{array}{l}\text { Unprocessed } \\
\text { cortical bone }\end{array}$ & $\begin{array}{l}\text { Steriliezed } \\
\text { cortical bone }\end{array}$ & $\begin{array}{l}\text { Cortical bone } \\
\text { preserved in } \\
\text { glycerol }\end{array}$ \\
\hline VL1 & $\mathrm{M}$ & POODLE & NI & - & - & - & - \\
\hline VL2 & M & BASSET HOUND & 2 years & CONT. & CONT. & CONT. & CONT. \\
\hline VL3 & $\mathrm{F}$ & POODLE & 5 years & + & + & - & - \\
\hline VL4 & $\mathrm{F}$ & COCKER SP. & 9 years & CONT. & CONT. & CONT. & CONT. \\
\hline VL5 & $\mathrm{F}$ & TECKEL & 5 years & + & + & - & - \\
\hline VL6 & $\mathrm{F}$ & PIT BULL & 6 years & + & - & - & - \\
\hline VL7 & $\mathrm{F}$ & AKITA & 12 years & + & - & - & - \\
\hline VL8 & M & BRAS. FILA & 2 years & + & + & - & - \\
\hline VL9 & $\mathrm{F}$ & MO & 3 years & - & - & - & - \\
\hline VL10 & $\mathrm{F}$ & SCHNAUZER & 5 years & + & + & - & - \\
\hline VL11 & $\mathrm{F}$ & MO & 2 years & - & - & - & - \\
\hline VL12 & $\mathrm{F}$ & BEAGLE & 7 years & + & + & - & - \\
\hline VL13 & M & MO & 4 years & CONT. & CONT. & CONT. & CONT. \\
\hline VL14 & $\mathrm{F}$ & MO & 9 years & + & - & - & - \\
\hline VL15 & $\mathrm{F}$ & POODLE & 9 years & + & - & - & - \\
\hline VL16 & M & MO & 10 years & - & - & - & - \\
\hline VL17 & $\mathrm{F}$ & DÁLMATIAN & 8 years & - & - & - & - \\
\hline VL18 & $\mathrm{F}$ & MO & 6 years & - & - & - & - \\
\hline VL19 & $\mathrm{F}$ & MO & 3 years & + & + & - & - \\
\hline VL20 & $\mathrm{F}$ & MO & 1 year & - & - & - & - \\
\hline VL21 & M & MO & 2 years & + & + & - & - \\
\hline VL22 & M & PIT BULL & 6 years & + & + & - & - \\
\hline VL23 & $\mathrm{F}$ & MO & NI & + & + & - & - \\
\hline VL24 & M & SCHNAUZER & NI & + & + & - & - \\
\hline VL25 & $\mathrm{F}$ & BASSET HOUND & 11 years & + & + & - & - \\
\hline VL26 & M & $\mathrm{MO}$ & 1 year & + & + & - & - \\
\hline VL27 & $\mathrm{F}$ & MO & 7 years & - & + & - & - \\
\hline VL28 & M & TECKEL & 8 years & CONT. & + & - & - \\
\hline VL29 & $\mathrm{F}$ & MO & 5 years & + & + & - & - \\
\hline VL30 & M & MO & 6 months & + & - & - & - \\
\hline VL31 & $\mathrm{F}$ & ROTWEILLER & 1 year & - & - & - & - \\
\hline VL32 & M & MO & 2 years & + & + & - & - \\
\hline VL33 & $\mathrm{F}$ & BOXER & 3 years & - & + & - & - \\
\hline VL34 & M & AKITA & 9 months & + & + & - & - \\
\hline VL35 & $\mathrm{F}$ & LABRADOR & 3 years & - & - & - & - \\
\hline VL36 & $\mathrm{F}$ & MO & 7 months & + & - & - & - \\
\hline VL37 & $\mathrm{F}$ & MO & 1 year & + & + & - & - \\
\hline VL38 & $\mathrm{F}$ & BORDER COLLIE & 3 years & + & - & - & - \\
\hline VL39 & M & LABRADOR & 8 months & + & - & - & - \\
\hline VL40 & $\mathrm{F}$ & MO & 2 years & + & + & - & - \\
\hline VL41 & $\mathrm{F}$ & PINSCHER & 8 years & + & + & - & - \\
\hline VL42 & M & MO & 1 year & + & + & - & - \\
\hline
\end{tabular}

Legend: VL: Visceral leishmaniasis; M: Male; F: Female; MO: Mongrel; NI: Age not informed; CONT.: Contaminated sample; +: Positive growth of Leishmania; -: No growth of Leishmania. 


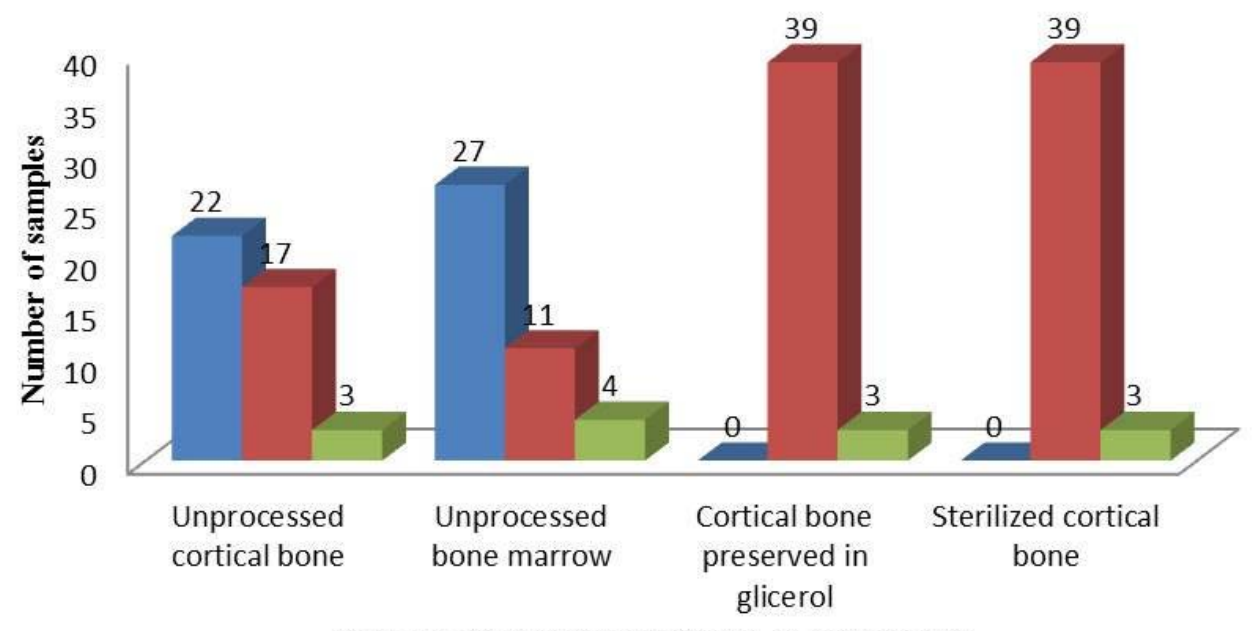

Culture of promastigote forms os Leishmania

Positive Negative Contaminated

Figure 2. Number of positive, negative and contaminated samples in culture of cortical bone and bone marrow without treatment (unprocessed) and in cortical bone subjected to autoclaving or storage in glycerol, from dogs naturally infected with Leishmania. $\mathrm{n}=42$.

Storage in glycerol for 30 days was an effective technique for the destruction of the parasite, which suggests that bone grafts after this processing would not transmit infection of $L$. infantum to the transplant recipient $\mathrm{dog}$. Bacteriostatic or bactericidal effects of glycerol are reported in the literature (Del Carlo et al., 1999; Giovanni et al., 2006). This antimicrobial capacity is because glycerol is a fast fixative and dehydrating agent, acting as a powerful antiseptic (Alvarenga, 1992). The same could explain the efficacy of the product in the elimination of Leishmania sp.

There is limitation in the bactericidal activity of glycerol, i.e., not all types of bacteria are affected by it even after 30 days of storage. Glycerol may have a bacteriostatic activity, as demonstrated in studies by Del Carlo et al. (1999) instead of a bactericidal activity, as mentioned by other authors (Gioso et al., 2002, Giovani et al., 2006).

Due to the presence of agents that make DNA extraction from cortical bone difficult, such as calcium, PCR after storage under glycerol was not performed, because the method requires a starter-specific product. It is important to assess the future presence of parasite DNA in the cortical bone after storage under glycerol in order to reduce the possibility of graft rejection.

Sterilization by autoclaving is also effective to prevent Leishmania from being transmitted to a recipient animal from a bone graft. The literature already addresses autoclave sterilization efficacy against microorganisms, particularly bacteria (Hooe and Steinberg, 1996). In addition, the temperature used for sterilization is much higher than that quoted by other authors as lethal to the parasite (Raina and Kaur, 2006).

Cortical bone PCR after autoclaving for detection of DNA from $L$. infantum was not performed for the same reasons mentioned for the samples stored in glycerol. The literature, however, mentions a reduction in the amount of DNA when employing this type of sterilization. Gefrides et al. (2010), after autoclave sterilization of materials containing saliva for different periods of time, concluded that the number of alleles detected decreased with increasing time of sterilization, and, after 60 minutes, more than $75 \%$ of the profile had already been deleted. Nevertheless, vaccines made with various autoclaved Leishmania species were tested for production of effective immune response against the parasite and 
succeeded, proving the existence of an antigenic capacity (Srivastava et al., 2003 and Nagill et al., 2009). Thus, more detailed studies on the elimination of Leishmania DNA from bone grafts after sterilization in different periods, temperatures and pressures are needed, as well as an analysis of the mechanical strength of the material for each chosen time sequence to check the integrity of bone in each case and the inflammatory response produced by the graft in the recipient. Whether maintenance of osteogenic, osteoinductive and osteoconductive properties occurs should also be assessed, as they are very important to the success of the graft. Thus, it may be possible to select the best combination among the percentage of DNA removed, maintenance of osteoconductive, osteogenic and osteoinductive properties and mechanical strength of the graft material.

Because both types of bone processing were successful in eliminating the parasite in question, the best technique for the preservation of bone depend on other factors, such as the mechanical resistance of the material, the type of collection from the donor (aseptic or not), the capacity of the material for osteogenesis, osteoinduction and osteoconduction and the cost of the technique. In this study, we chose the techniques of storage in glycerol and autoclave sterilization due to their low cost and ease of implementation along with the quality they provide to the graft. It is important to mention, though, that both have limitations, such as the reduction of mechanical strength in autoclaved tissues and reduction of osteogenic capacity in both techniques. Thus, other techniques for processing bone should also be studied in the future for the elimination of Leishmania, given that each has its advantages and limitations that must be analyzed to choose the best technique to be applied in each case, as described in literature (Fitch et al., 1997; Boyce et al., 1999; Giovani et al., 2006).

Thomson and Sinton (1921) observed growth of $L$. infantum in NNN medium, the same used in this study, with a sample of bone marrow from a corpse after 14 hours postmortem, claiming the high internal resistance of the parasite in tissues without specifying the mechanisms involved. In this study, we were able to isolate the parasite from samples collected 48 hours post- mortem. However, no samples from animals whose postmortem period was more than 48 hours were harvested to prevent risks of contamination due to the decomposition of the bodies, which could harm the growth of promastigotes in untreated samples. A more detailed evaluation of parasite growth in cadavers with a postmortem period greater than 48 hours is required to gain further insight into the mechanisms of resistance of Leishmania sp.

There have been few studies of the changes in cortical bone caused by leishmaniasis. Papers about cortical changes mainly refer to cases of osteomyelitis with lytic characteristics in cortical and inflammatory infiltrate (Costa et al., 2006; Santos et al., 2006). These changes, however, are macroscopic and visible radiographically at this stage, and such bone would not be included in a bone bank. Thus, we need more mechanical and histological studies of the cortical bone and its composition of hydroxyapatite and collagen which are responsible, respectively, for the stiffness and elasticity of bone tissue (Serakides, 2011), to verify that an apparently healthy sample shows no injuries and/or microscopic changes in its composition that would compromise the mechanical functions of the graft.

\section{CONCLUSIONS}

Autoclaving and conservation of the L. infantuminfected bone in glycerol for 30 days prevented parasite growth in vitro. Further studies, including DNA identification of this agent in the bone by the tested techniques, are required to verify the complete elimination of the parasite in the tissue.

\section{REFERENCES}

ALVAR, J.; CAÑAVATE, C.; MOLINA, R. et al. Canine leishmaniasis. Adv. Parasitol., v.57, p.1-88, 2004.

Alvarenga, J., 1992. Possibilidades e limitações da utilização de membranas biológicas preservadas em cirurgia. In: Daleck, C. R. (Ed.), Tópicos em cirurgia de cães e gatos. Jaboticabal: Fundação de Estudos e Pesquisas em Agronomia - Universidade Estadual Paulista de Botucatu, pp.33-39. 
BANETH, G.; KOUTINAS, A.F.; SOLANOGALLEGO, L. et al. Canine leishmaniosis - new concepts and insights on an expanding zoonosis: part one. Trends. Parasitol., v.24, p.324-330, 2008.

BOYCE, T.; EDWARDS, J.; SCARBOROUGH, N. Allograft bone. The influence of processing on safety and performance. Orthop. Clin. N. Am., v.30, p.571-581, 1999.

CAVASSANI, M.M.; MORAES, J.R.E.; FILHO, J.G.P. Função osteoindutora de fragmentos ósseos conservados em glicerina a 98\%: estudo experimental em ratos. Ciênc. Rural., v.31, p.445-448, 2001.

COSTA, A.A.; ABREU, A.L.; GOMES, C.M. et al. Experimental model of chronic osteomyelitis caused by Leishmania (L) amazonensis. Acta Trop., v.98, p.125-129, 2006.

DEL CARLO, R.J.; GALVÃO, S.R.; VILORIA, M.I.V. et al. Aloenxertos ósseos caninos diferentemente preservados. Rev. Bras. Cienc. Vet., v.6, p.121-126, 1999.

EVANS, D. Handbook on isolation, characteriztion and criopreservation of Leishmania. Geneva: UNDP/World Bank/WHO, 1989. 45p.

FERREIRA EDE, C.; DE LANA, M.; CARNEIRO, M. et al. Comparison of serological assays for the diagnosis of canine visceral leishmaniasis in animals presenting different clinical manifestations. Vet. Parasitol., v.146, p.235-241, 2007.

FITCH, R.; KERWIN, S.; NEWMAN-GAGE, H. et al. Bone autografts and allografts in dogs. Comp. Cont. Educ., v.19, p.558-574, 1997.

FREITAS, E.; MELO, M.N.; COSTA-VAL, A.P. et al. Transmission of Leishmania infantum via blood transfusion in dogs: potential for infection and importance of clinical factors. Vet. Parasitol., v.137, p.159-167, 2006.

GEFRIDES, L.A.; POWELL, M.C.; DONLEY, M.A. et al. UV irradiation and autoclave treatment for elimination of contaminating DNA from laboratory consumables. Forensic Sci. Int. Genet., v.4, p.89-94, 2010.
GIOSO, M.A.; BENITES, N.R.; KÄMPF, G. Análise microbiológica de ossos de cães conservados por longo período de tempo na glicerina a $98 \%$ à temperatura ambiente, objetivando a enxertia óssea. Acta Cir. Bras., v.17, p.242-246, 2002.

GIOVANI, A.M.; CROCI, A.T.; OLIVEIRA, C.R. et al. Comparative study of cryopreserved bone tissue and tissue preserved in a $98 \%$ glycerol solution. Clinics, v.16, p.565-570, 2006.

GOMES, A.P.S.; CORDEIRO, R.L.R. Reação cruzada no diagnóstico sorológico de leishmaniose canina. Rev. Bras. Parasitol. Vet., v.23, p.238, 2004

HOOE, W.; STEINBERG, B. Management of contaminated bone grafts: an experimental in vitro study. Oral Surg. Oral Med. Oral Pathol. Oral Radiol. Endod., v.82, p.34-371, 1996.

LEISHMANIOSE Visceral. Situação epidemiológica. Brazilian Ministry of Health, 2012. Disponível em: $<$ http://portal.saude.gov.br/portal/saude/profissio nal $/$ area.cfm?id_area $=1561>$. Acessado em: 20 nov. 2012.

MANCIANTI, F.; PEDONESE, F.; POLI, A. Evaluation of dot enzyme-linked immunosorbent assay (dot-ELISA) for the serodiagnosis of canine leishmaniosis as compared with indirect immunofluorescence assay. Vet. Parasitol., v.65, p.1-9, 1996.

MORELLO, E.; BURACCO, P.; MARTANO, M. et al. Bone allografts and adjuvante cisplatin for the treatment of canine appendicular osteosarcorna in 18 dogs. J. Small Anim. Pract., v.42, p.61-66, 2001.

NAGILL, R.; MAHAJAN, R.; SHARMA, M. et al. Induction of cellular and humoral responses by autoclaved and heat-killed antigen of Leishmania donovani in experimental visceral leishmaniasis. Parasitol. Int., v.58, p.359-366, 2009.

NAVIN, T.R.; ARANA, F.E.; DE MÉRIDA, A.M. et al. Cutaneous leishmaniasis in Guatemala: comparison of diagnostic methods. Am. J. Trop. Med. Hyg., v.42, p.36-42, 1990.

RAINA, P.; KAUR, S. Chronic heat-shock treatment driven differentiation induces apoptosis in Leishmania donovani. Mol. Cell. Biochem., v.289, p.83-90, 2006. 
SAMPAIO, I.B.M. Estatística aplicada à experimentação animal. Belo Horizonte: FEPMVZ, 2002. 265p.

SANTOS, M.; MARCOS, R.; ASSUNÇÃO, M.; MATOS, A.J. Polyarthritis associated with visceral leishmaniasis in a juvenile dog. Vet. Parasitol., v.141, p.340-344, 2006.

SERAKIDES, R. Ossos e Articulações. In: SANTOS, R.L; ALESSI, A.C. Patologia veterinária. Roca, São Paulo; 2011. p. 647-696.

SOLANO-GALLEGO, L.; RODRIGUEZ-CORTES, A.; TROTTA, M. et al. Detection of Leishmania infantum DNA by fret-based real-time PCR in urine from dogs with natural clinical leishmaniosis. Vet. Parasitol., v.147, p.315-319, 2007.

SRIVASTAVA, J.K.; MISRA, A.; SHARMA, P. et al. Prophylactic potential of autoclaved Leishmania donovani with BCG against experimental visceral leishmaniasis. Parasitology, v.127, p.107-114, 2003.
TAFURI, W.L.; OLIVEIRA, M.R.; MELO, M.N. et al. Canine visceral leishmaniosis: a remarkable histopathological picture of one case reported from Brazil. Vet. Parasitol., v.96, p.203-212, 2001.

THOMSON, J.G.; SINTON, J.A. Leishmania donovani, in cultures, recovered from spleen during life and from the bone marrow of the cadaver. Proc. R. Soc. Med. Sect Trop. Dis. Parasitol., v.14, p.21-23, 1921.

TORRES, B.T; CHAMBERS, J.N.; BUDSBERG, S.C. Successful cementless cup reimplantation using cortical bone graft augmentation after an acetabular fracture and cup displacement. Vet. Surg.,v.38, p.87-91, 2009.

TRONCARELLI, M.Z.; MACHADO, J.G.; CAMARGO, L.B. et al. Associação entre resultados sorológicos no diagnóstico da leishmaniose e da tripanossomíase canina, pela técnica de imunofluorescência indireta. Vet. Zootec., v.15, p.40-47, 2008. 